\title{
Cultural Heritage Tourism Management in Pashupatinath Area
}

\section{Pashupati Nyaupane}

\begin{abstract}
Heritage represents irreplaceable resources for the tourism industry so conservation is a vital component of their management. Throughout the world, the tourism industry has been an economic generator including conserving the heritage sites. Today, tourism has been considered to have greater socio economic values. Thus Pashupatinath area, with its rich cultural heritage, has great potential to be tapped through cultural heritage tourism. Pashupatinath area is known for its rich cultural heritage, but lack of proper tourism guidelines in the areas has not been able to showcase its potential. Thus, the paper tries to bring the importance of heritage tourism in the core area of Pashupatinath and its vicinity into limelight. The paper addresses the need of improvement in management, information and development in infrastructure. Moreover it covers the approach of conservation of tangible and intangible cultural heritage. This article examines the significance and value of Pashupatinath area as a cultural heritage tourism destination. This research identifies numerous issues related to cultural heritage tourism management in Pashupatinath area and its cultural heritage tourism products, coordination among stakeholders and interpretation. It explores the current management situation of Pashupati area and provides the suggestion for the betterment of cultural heritage tourism in Pashupatinath area. The paper helps to relate the tourism industry with the economic growth of Pashupatinath area.
\end{abstract}

Key words: Heritage, Cultural Heritage tourism, Interpretation, Authenticity.

\section{Introduction}

Hinduism is known as one of the most ancient religions in the world. Actually there are four most prominent religious cults in the philosophy arena of Hindu, i.e Shaivism, Shaktism, Vaishnavism and other are minor cults (Koirala, BS 2051, p. 316). Though, the four religious cults are fundamentally different in terms of their religious and spiritual 
ideologies, all of them glorify Pashupati worshipping as one of the highest spiritual offering and all of them accept Lord Pashupatinath as 'devaadidev' i.e. god of all gods/goddesses.

Pashupatinath area is one amongst the major religious and pilgrimage destination for Hindus in general, most importantly for Saivamargis. Its popularity is related to its antiquities, religious faith, mythologies and legends. Based on the interviews with people belonging to the various religious background such as Hinduism, Buddhism, Kirats, Sikha and Jains. For preparing this research paper, the conclusion drawn out was that the religious significance of Pashupatinath temple is limited not only amongst the Hindus but also among the people of other religions. However, a much larger group of cultural tourists visitthis site to relish the experience of a rich living heritage. Cultural heritage tourism management requires attentive management on service quality, cultural infrastructure development, interpretation, product development. Product diversifies, accommodation, access to internet and maintaining authenticity (Gupta, 2002, p.29). The management of cultural heritage tourism is necessary for better achievement of sense of satisfaction for tourists through conservation and preservation of heritages that ultimately boosts the economy (Nyaupane, 2017, P.31). The aim of this research is to explore and identify the cultural heritage management in Pashupati area. This article is based on qualitative research methodology. As a primary source of data collection interview were conducted with local residents, Indian visitors and other international visitors in Pashupati area and a (FGD)focused group discussion with officers of PADT, local authorities were carried out. Similarly, for secondary sources of data collection, books and articles were consulted.

\section{Heritage tourism Management}

The management of heritage becomes vital for its long term sustenance. For the proper management of heritage sites it is of foremost importance to conserve and preserve and then to promote and market it. Also, numerous other components such as resource, infrastructure, visitors flow, financial management too can be incorporated. Thus the conservation, preservation, promotion and marketing are vital for its sustainability (Gupta, 2002, p.28).

While discussing about managing cultural heritage tourism, proper consideration of conservation at heritage site becomes the key factor for tourism development which would otherwise lead to excessive commodification of such heritage site. Various international and national organizations have been playing significant part in the management and conservation of cultural heritage sites. For example, International Council of Museum (ICOM), International Council on Monuments and Sites, (ICOMOS), United Nations Educational, Scientific and Cultural Organization (UNESCO), the International Federation of library Associations and institution ( IFLA), the organization of world heritage cities (OWHC), and the World Monuments Fund (WMF) (Park, 2014, p. 44). 


\subsection{Cultural Heritage}

The term heritage has broader meaning which is generally associated with the word 'inheritance' which means something transferred from one generation to another. The Oxford dictionary meaning for inheritance goes for that which has been transmitted from the past or handled down by tradition. Heritage is the legacy left behind by the generations that came before us. Heritage is defined as natural, cultural and built environment of an area (Gupta, 2002:60). The term heritage has broader meaning which is generally associated with the word 'inheritance'. It means something transferred from one generation to another. Cultural heritage is the place, period of time, objects, ideology and creation that shows the cultural and geographical prosperity of any country (Park, 2014, p. 17). Cultural heritage is an expression of the ways of living developed by a community and passed on from one generation to another generation (Nyaupane, 2019, p. 86).The Oxford dictionary meaning for inheritance goes for that which has been transmitted from the past or handled down by tradition. Heritage is the legacy left behind by the generations that came before us. Heritage is defined as natural, cultural and built environment of an area (Gupta, 2002, p. 60). Heritage is understood from a broader concept and includes all the tangible-intangible components of the past that are of universal value. Heritage can be broadly divided into natural and cultural heritage. Cultural Heritage is an expression of the ways of living developed by a community and passed on from one generation to another generation including customs, practice, places, objects, artistic expressions and cultural values. Heritage is often expressed as either tangible or intangible cultural heritage (ICOMOS, 2002). Cultural Heritage incorporates tangible and intangible remnants of the past (Park, 2014, p. 12). Intangible cultural heritage is a collection of beliefs, faith, habits, practices, customs, traditions, morality, skill, though, religious practices, value, attitude, perceptions. Similarly, the tangible form of cultural heritage refers to the productive forces to support human life such as museums, art, architecture paintings, monument, structures heritage building fort, ancient cities. Such heritages are transmitted from generation to generation within a community. Heritage works as a guideline that represents the ideology and authenticity of the past (Smith, 2006, p. 12). Heritage is the identity and symbol of a particular community which has been developed over a course of time, in a certain civilization.

\section{Cultural heritage tourist}

Cultural heritage tourists are those who are motivated and inspired to explore, investigate and experience culture and heritage of destinations foreign to them. Taylor mentions(1993,p. 35) serious heritage tourists are often well educated with higher qualification in education as well as socio-economic backgrounds. Therefore, they prefer to stay longer and have in depth experience and knowledge of both the tangible and intangible cultural heritage. They are better qualified in education as well as socio-economic background, their motivations is higher, raising the demand side of heritage, hence the interpretation, 
representations and overall management strategies are made. He further mentions that Heritage tourist are much more than other general tourists. Therefore, they seek to get maximum information about their destinations, increase academic interest and emotional connections to appreciation and have personal valuable relation with heritage sites. (Park, 2014, p. 44).

\section{Cultural heritage tourism}

Cultural heritage have long contributed to attract the cultural heritage tourists in the socio-cultural, religious, archaeological sites. Recent years cultural heritages have been rediscovered as an important marketing tool to apple those travelers with special interest in heritage sites. People visiting cultural, historical, archaeological and religious resources are one of the largest and fastest growing sectors of the tourism industry in modern day. (Timothy and Nyaupane, 2017, p. 3).

As defined by The National Trust for Historic Preservation, "Cultural heritage tourism is traveling to experience the places, artifacts and activities that authentically represent the stories and people of the past and present. It includes cultural, historic, and natural resources. "(ICOMOS, 1997) As the primary purpose is to the visit historical, cultural, archaeological and religious sites.

Cultural heritage tourism is a complex form of tourism in comparison to other forms of tourism (Macchnnell 1979, p. 22). At the heritage sites, tourists come with various motivation and demands. It has to consider various factors of conservation and preservation of the site, maintaining the authenticity and commodification, presentation and interpretation the heritages diversification and marketing, infrastructure development visitor's management and human and hospitality aspects (Park, 2014, p. 44). Meanwhile, visitors' satisfaction, trail management, product development, product diversification, development of modern facilities, establishment of research centers, accessibility, accommodation, interpretation, ethical issues in and around are also major issues in the heritage sites. Hence, it has great challenges to cope with the visitors' expectation and the ethical issues in heritage site. Notably, in the postmodern period of tourism, cultural heritage tourism is generating more attention and attraction. Pashupatinath is one of such cultural heritage tourism destination where people gain experience of past tangible intangible heritages and well as experience the living heritages.

\section{Management of cultural heritage Pashupati area}

Pashupati area, which is culturally, religiously, archaeologically, and naturally wellrenowned, is a precious heritage not only to Nepal and its inhabitants, but also to the world and is hence worth preserving. All the shrines, temples, shelters, monasteries, and stupas that are located in this area need to be preserved in their prototypical ancient forms while 
the spiritual and natural environment around them need to be protected (Tandan , B.S.2053, p. 598).Since the very beginning of the establishment of main temple of Pashupatinath and other numerous monuments, all of its necessary management aspects were being looked after by the loyal authorities, local social organizations, general people, Guthi system and pilgrims. It was in $2044 \mathrm{BS}$, after the establishment of PADT that the overall responsibility of thethe development, promotion, maintenance, management was channelized to this trust. At present the trust has become the core leading authority for the development of Pashupati area. Services and activities of all the authorities like GuthiSamsthan, local government, local stakeholders and other national and international organizations are under the directions guided by PADT (Tandon, B.S. 2053, and P.99).

Pashupati area is primarily a religious and pilgrimage site which also serves as a cultural heritage destination because of its antiquities, monuments, cultural landscape, socio cultural practice, religious belief, religious activities, geographical structure, different culture's symbol, rituals, festivals, norms and values (Nyaupane, 2018, p. 8). Thus it is regarded as one of the most important pilgrimage, religious, cultural, archaeological and historical destination for Hindus and cultural heritage tourists. This site is supported not only by literature, legends, myth, religious text, but also by historical evidences such as dated inscriptions, dated icons, coins, antiquities and monuments located at the bank of Bagmati Holy River which is symbol of civilization of Kathmandu valley (Aryal).

\section{Situation analysis of study area}

Despite its popularity there has never been extensive study of its visitation nor has there been a comprehensive study of its conservation and preservation from the point of view cultural heritage tourism. Furthermore, ineffective visitor management at heritage sites with a lack of study of carrying capacity, environmental impact, and ecological balance in resources will aggravate the degradation and destruction of heritage sites. So, for the proper management of Pashupati area, the academic suggestion, participation and involvement of various experts as well as local participation is essential for the long term sustainability of this site. At Pashupati area, there has been an inflow of cultural heritage tourists over the years. However, the concerned authority has not taken any measure to improve or increase the supply of tourism requirement in relation to what the heritage tourists seek at heritage sites. The certified local guides were found to have been lack of in depth knowledge to provide interactive narratives and interpretation of the heritage site, during the interview with the seven guides working there. Furthermore, information panels, guide desk, audiovideos place and theatre are not found in this area. Pashupati area has been world famous for pilgrimage among global Hindus, Buddhist and Kirant but still in this $21^{\text {st }}$ century there is less practice, priority and consideration of heritage tourism. Cultural heritage tourism has great potentialities due to its ancient history, living heritage, majestic art and architecture i.e. incomparable to others in the world. Pashupati area has unnoticeable development in 
cultural heritage tourism either in the matter regarding tangible heritage or intangible heritage preservation, promotion, interpretation, product diversification, product development, visitor management, infrastructure development, service and facilities, accommodation sector or smooth operation and coordination of overall destination. Even the natural heritages like Holy River Bagmati, secret forest, caves, gorges, kunda and so on are not in serious focus for its conservation.

\section{Elements for managements}

There are certain important elements on the basis of which the cultural heritage tourism destination can be better managed.

Policy: The related institution involves as stakeholders have their own policy for management and development. Each organization has its own legislation, rules and regulation. For the smooth implementation of such legislation all the regulated organizations should have better coordination to apply exact and effective regulations for all. Ministry of culture, DOA, PADT, Ghuthi Sansthan, Local Governance are the major stakeholders for making budget, plan and policies for conservation and preservation.

Planning: Good management starts from good planning. Hereby, effective planning since the beginning of the task makes the management successful. Goals must be set, the means by which those goals will be evaluated must also be made clear and a specific time frame must be outlined and then adhered too. Performance management success requires clear goal setting. Similarly, Pashupati area is also lacking or in need of effective planning to evolve the concept and its implementation. Planning regarding programs, budget, essential manpower, use of technology, measurement of affectivity on project implementation, etc. should be focused for successful management. Even planning as per available statistics makes development work and its management sensible.

Budgeting: PADT is highly responsible to maintain the religious, spiritual, archaeological, historical and cultural significance. This site carries global value since 1979 after listing UNESCO World Heritage site. Pashupati area collects a large amount of money from different sources such as offering from devotees, special worshipping fee, donation for pilgrims and government funding. At the same time, it's a noticeable thing that PADT has collected 150 million rupees from entrance fee of non Hindu foreign visitors in 2017. Hereby, financial management has become the most important part of PADT to make it transparent, public and properly implemented for right cause. There are lots of development works that need to be done in PADT. So, the proper management of finance should be initiated in this area such as, conservation and preservation of tangible cultural heritages, infrastructure and super structure development, implementation and use of the information technology, maintenance of safety and security, regular sanitation and management, Ashram management, managing 
event, festivals, ritual and programs, repairing and maintenance, promotion and publicity, accommodation and hospitality, human resources management.

Organizing: The leading team should compose of geniuses from various sectors in order to develop Pashupati area in various ways. The members can be as follows; any one from MOCTCA, NTB, NATTA, HAN, DOA, Culture expert, Historian, Environmentalist, IT, Architect engineers, management expert, financial expert and so on. Thus, creating the multidimensional committee has the expectation of incorporating diverse inputs in the committee for the overall development of PADT.

Coordination: Pashupati area is very sensitive, multi purposed, multidimensional cultural heritage site of Nepal where the diverse people, organizations and sectors should be involved. There are numerous cultural resources and activities available here. There should be coordination among PADT, government, UNESCO, other international organizations and local organizations for proper management and development.

\section{Present management modality in Pashupati area}

Management is a multidimensional activity and seeks to be integrated. It incorporates socio cultural economic, political, environmental, technological, religious and archaeological factors. (Bhatia, 1994, p. 36). In order to manage all the factors in Pashupati area,four different sectors are involved actively and responsibly. Based on the field observation, FGDs and interviews held with PADT officers and local stakeholders, following roles of various sectors were identified by them.

\section{Role of Private sectors}

Private sectors are the major stakeholders in Pashupati area. The souvenir shops, restaurants, hotels, street vendors and religious offering shops are the private stakeholders in this site. Despite their involvement in this area for their personal progress, economic benefits and interest. We cannot avoid their contributions directly or indirectly for providing the services and facilities. Actually they are providing service and facilities to their visitors. For proper authorization and management regarding the religious offering products and pricing of different items sold in stalls should be monitored by PADT. Registration and legalization process help to maintain the proper location and pricing police.

\section{Role of Public sectors}

Public sectors range from MOCTCA, DOA, PADT, Guthi Samsthan in this area. Hence, these sectors have key role for the overall management of the area such as planning, budgeting, conservation, promotion, monitoring, controlling and execution of all essentials. Moreover, they play a role to collaborate with the private sectors as well as the international sectors. Public institutions create good relation with the local to the visitors too to identify 
the situation problems and even for their remedial sources. Thus, public sectors have the task of infrastructural development to their overall management and the updated technology, governing system, international relationship. Guthi Samsthan is managing intangible heritage in this area.

\section{Public private partnership modality}

Overall management of Pashupati area is solo responsibility of PADT. Similarly, several various over private and public organizations, institutions and agencies are directly or indirectly involved. Mostly, during the fairs and festivals, event, ceremonies, and other religious processions and practices PADT and various other private and public institutions have been involved to contribute as per the sector involved. For instance, from government sectors Nepal police and Nepalese army involve in security management. Red Cross and various other medical institutions involve in blood donation, first aid and medical camps, Marwadi Sewa and other religion-social organization involved in visitor food. Nepal Scout groups and other groups involved in volunteering for crowd management, social security and rescue. Hence, various other institutions involved in various ways to contribute as per as their sector and coordination with PADT norms, rules and regulations.

\section{Collaboration with international sectors}

International sectors like UNESCO, ICOMOS, ICCROM and various other organizations have supportive role to develop and promote the world heritage site. The collective effort of public all the private and with international sectors can reap gigantic advantage of management.

\section{Finding for management in this area}

From the data analysis of information collected from the field observations, FGDs, interviews, this research paper has come up with following suggestions and recommendations.

\section{Management of Information}

- Information regarding regular worshipping, ritualistic activities, festivals and ceremonies should be disseminated through various communication such as newspapers, radio, TV, internet and other means of communications.

- Guide books in Nepali, Hindi, English and other needed languages can be published with the important information's about accessibilities, accommodation, amenities, road maps, guide service and activities to the visitors to visit and have a comfortable stay. 
- Information boards, signage, captions, maps and related information should be placed in heritage route, entrance gates, parking areas, in front of monuments etc. to facilitate visitors for their comfortable visit.

- PADT has already designated certain places for conducting, operating and performing different rituals, ceremonies and programs, in Pashupati area for attractions, services, facilities, security and the overall management.

- Information about the opening and closing of main doors of Pashupatinath temple in different seasons, events, festivals and so on should be provided. The daily routine should be made available for visitors to feel comfortable.

- The offering materials like flowers, garlands, Belpatra (Marmelous leaf/wood apple), Tulsipatra (basil leaf), Dhutura, Coconut, sacred water, chandan, Rosary beeds, (rudrakshya) sweets, etc. should be well packed in organic packaging and sold in economical price through official sales counter.

- Pashupati area should have proper place for the audience and performers for chanting Bhajans, (hymns) listening religious stories, tales, scriptures, etc. There should be awell managed comfortable place for all seasons to the devotees. Ram Mandir area is preferable for such religious musical performances.

- Properly trained guides should be appointed and coordinated by PADT to assist and brief the pilgrims within the heritage site.

\section{Security management}

- Tourist police should be regulated to ensure the security of visitors and to assist them in need.

- Even the civil police or armies can be appointed and stationed to the major monuments, junctions, entrances and others in need.

- Well secured managed system and governance of PADT can open the Eastern and Southern gate every day.

- Special functions and festivals should be managed properly with the team work of Civil Police, Scouts, Red Cross Society, various other volunteering groups and local clubs in order to provide the visitors with proper and systematic access alone with the facilities like drinking water, first aid and so on.

\section{Facilities and services}

- Accommodations with the facilities of totally vegetarian cuisine should be managed extensively as per the need of pilgrims. 
- Traditional concept of Dharmasalas should be modernized in technological and scientific way with assured hygiene, comfort

- Well managed parking zone with security system of CCTV, time allotment, parking fee, separate entry and exit facilities should be maintained.

- Physically disable visitors should have wheel chair friendly tracks and support to ensure their safe and comfortable visit. Wheel chair facilities should be made for the senior citizens.

- Separate places should be allocated for storing the visitors' leather items like shoes, slippers, belts, wallets, electrical appliances like mobile phones, cameras, laptops etc.

- Hygienic and dry toilets, urinals and bathrooms should be well developed at various points.

- Bathrooms nearby Baghmati River around Pashupatinath area are essential after holy bath into the river.

- Safe drinking water area should be provided with treated drinkable water.

- Aaryghat and Bhashmeshwor Ghat should have separate area for hair shaving and changing clothes.

- Separate area should be allocated and managed for rituals such as Janai Purnima Guru Purnima, Aunshi (No moon night), Shraddha (yearly death ritual) etc.

- The Pashupati area should develop and extended proper facilities such as accommodation, food, library, information center to the varying range of visitors.

- Bolbam pilgrims, arriving late at night should be facilitated either to worship Pashupati or they should be facilitated to proper tents facilities with basic refreshments.

- During the special events certain entrance and route can be used. They are:

a) Tilganga to main temple square via southern gate.

b) Pinglasthan to main temple square via southern gate.

c) Gaushala to Pashupati via right hand side inclined way nearby Bankali and entering through southern gate.

d) Gaushala to Pashupati via left hand side road to enter through Western gate across Bhuwaneshwari temple.

e) The inclined street straight across Jayabageshwori to western gate.

f) The inclined street from Mitra Park to western gate via Daxinamurty temple. 
g) Guhyeshwori to Eastern gate via Gorkhanath Aaryaghat.

h) Northern and Eastern gates can be used as exit to the pilgrims.

\section{Conclusion}

Pashupati Area is the focal point of Hindus in the World. It has a great importance from heritage tourism point of view with socio-cultural, religious, historical and aesthetic values. Although,it is one of the most potential destinations for cultural heritage tourism, enough comprehensive and motive oriented surveys are yet to be conducted on the topic of management and its development. PADT is responsible for the overall management of the destination and it has been providing services and facilities to pilgrims for the regular function and festivals. Volunteers are appointed temporarily for the cleanliness, line management, health facilities and security system during the festivals and special occasion. However, proper scientific planning and management cannot be seen. In this regard greater management faculties should be provided to increase its value, image building of the destination and diversification of various products. Notably, the tangible assets like temples, inns, crematoria area, water spouts, and various antiquities even the holy river: Bagmati have the serious matter regarding the preservation, protection, monitoring, promotion, time and situation friendly development and management as per the norms of UNESCO World Heritage site. However, this situation has not been experienced at Pashupatinath area mainly because the government of Nepal has not taken active steps to promote as a cultural heritage tourism destination. Moreover, different stakeholders like UNESCO, DoA, Guthi Samstan, Local organizations, local government have not been serious on the development of cultural heritage tourism. PADT has not been able to take proper steps so as to promote and develop this site as a cultural heritage destination. Experts in the field of cultural heritage like conservators, archaeologists, museologists, historians and tourism experts and economists are necessary for the complete management system in Pashupati area.

\section{References}

Aryal, S. H. (n a) Pashupati kshetrako samagra bhewasthapan, (overall management of Pashupatinath area), PADT, Kathmandu, Nepal.

Bhatia, A.K. (1997).Tourism Development, principal and practices, New Delhi: Sterling Publications.

Chauhan, S. Y. (2004). Eco-tourism in Nepal. Delhi: Kalinga Publication.

Ghosh, B. (1998). Tourism and travel management. Delhi: Vikas Publishing House Pvt. Ltd.

Gupta, S.K. (2002), Tourism and heritage resources in Garhwal Himalaya. New Delhi: Sk. Gupta.

ICOMOS charter for cultural tourism (1997). http://www. icomos.org/tourism/ 
Koirala,K.(2051B.S.). Nepal kha Aaradhyadev, bhagban Shree Pashupatinath, (Nepal Rajkiya Pragya Pratisthan, Kamladi, and Kathmandu: Auther.

Kunwar, R.R. (1997). Tourism and development science and industry interface, Kathmandu: Laxmi Kunwar Tiwari, S. R. (2013). Temple of the Nepal valley, Kathmandu: Himal Books.

Macchnnell, D. (1076), The tourist: A new theory of the leisure class London: Macmillan. Heritage tourism, (2014), National trust for historic preservation. Retrievation 4 April 2014. Shrestha, S. S. (2073 BS), Swayambhu: A World heritage destination, (Conservation and Management System), Paris: Oriental Cultural Heritage Sites Protection Alliance (OCHSOA).

Timothy, D. J. Nyaupane G. P. (2019). Cultural heritage and Tourism In The development world, London: Rutledge, (Special Nepal Edition).

Nyaupane, P. (2019). Cultural heritage tourism in Pashupatinath area,Journal of Nepal Mountain Academy, Kathmandu: Nepal Mountain Academy, College of Mountaineering vol.1 p.86- 102.

Nyaupane, Pashupati (2018). Pashupati Kshetrako Dharmik Sanskritik Prayatan Bikashko Parambhik Yojana, Pashupati bikashkosh.(Unpublished report).

Nyaupane, P. (2018), Potentials of Cultural Heritage Tourism in Nepal, Nepal Heritage Special, Kathmandu: Information Department, years 48, Number 2, P.197-221.

Taylor, K (2004) Cultural heritage management: A possible role for charters and principles in Asia, International Journal of Heritage Studies, 10(5):417-33.

Tiwari, S. R. (2013). Temple of the Nepal valley, Kathmandu: Himal Books.

Tandan, G. (2053 BS), Pashupati Kshetrakosanskritik Adhyan Kathmandu: Shri jharendra shamsher Ja Ba Ra and Shrimati Manju Rana.

Park, Y. H. (2015). Heritage tourism. Routledge: New York.

Smith, L. (2006) Uses of Heritage. New York: Rutledge. 